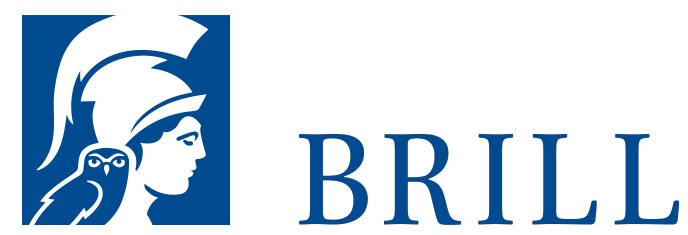

\title{
Mission Sitting Bull
}

\section{Die Geschichte der katholischen Sioux}

Author: Manuel Menrath

Ein nahezu unbekanntes Kapitel in der Geschichte der indianischen Urbevölkerung der USA wird entdeckt: die Bekehrung der Sioux. Manuel Menrath nimmt seine Leser mit in die Zeit des »Wilden Westens « und an die Orte eines Geschehens, an das sich die heutigen Angehörigen dieses Volkes vielfach nur mit Trauer und Bitterkeit erinnern. Kaum jemand in Europa weiß, dass heute ein Großteil der Sioux der katholischen Kirche angehört. Einst galten sie als das kriegerischste Volk auf dem Gebiet der heutigen USA. Unter ihren Anführern Red Cloud und Sitting Bull lehrten sie die weißen Eindringlinge das Fürchten. Doch als die Büffel beinahe ausgerottet waren und die Armee ihre letzten Jagdgründe besetzte, mussten sich die Krieger mit ihren Familien ins Reservat begeben. Dort wurden sie vom Benediktiner Martin Marty aus Einsiedeln zusammen mit deutschen und schweizerischen Gehilfen missioniert und »zivilisiert «. Das Buch erzählt erstmals diese Bekehrungsgeschichte, der Martin Marty sein Leben widmete. Dem Kirchenmann wurden Ehren und Wertschätzung bis heute zuteil. Von indianischer Seite hingegen wurde die Missionierung als Trauma und Tragödie erlebt: Zu spät erkannten sie, dass der neue Glaube nicht mit dem alten verbunden werden durfte.

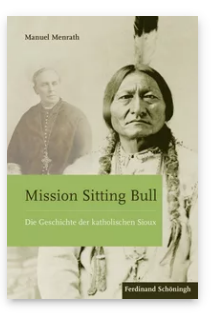

Pages: 373

Seiten, $50 \mathrm{~s} / \mathrm{w}$

Abb.

Language:

German

Subjects:

Cultural History,

Literature and

Cultural Studies

Publisher: Brill |

Schöningh

E-Book (PDF)

Released online:

22 Jun 2020

ISBN: 978-3-

657-78379-3

List price

Hardback

Publication date: 10 Jun 2016

ISBN: 978-3506-78379-о

List price 
Biographical Note

: Manuel Menrath ist Oberassistent am Historischen Seminar der Universität Luzern.

For more information see brill.com

\begin{abstract}
Order information: Order online at brill.com
+44330 333 0049 | customerservices@brill.com

Submission information: brill.com/authors
\end{abstract}

Titles published by Brill | Fink, Brill | mentis or Brill| Schöningh:

+49(o)71 5413279216 | brill@brocom.de 